\section{Linking critical thresholds for acidity to forest condition by using element contents in tree rings: consequences for the development of an integrated ecosystem assessment}

\author{
Augustin S \\ In the frame of the International Co-operative Programme on the Assessment \\ and Monitoring of Air Pollution Effects on Forests, results are given here on the \\ link of element fluxes through forests to $\mathrm{Mn}$ contents in tree rings in order to \\ detect incipient soil acidification.
}

Keywords: Critical loads, Critical limits, Acidification, Soil chemistry, Tree rings

\section{Introduction}

Due to the growing public awareness of possible adverse effects of air pollution on forests, in 1985 the International Co-operative Programme on the Assessment and Monitoring of Air Pollution Effects on Forests, the ICP Forests, was launched under the Convention on Long-range Transboundary Air Pollution (LRTAP Convention) of the United Nations Economic Commission for Europe (UNECE 2004).

The aim of the two stage forest monitoring on Level I and Level II of the ICP Forests is the scientific support of political decisions by means of the identification and quantification of indicators for forest condition and their change over time. The monitoring on the regularly distributed $(16 \mathrm{~km} \mathrm{x} 16 \mathrm{~km}$ grid) Level I plots aimed at detection of spatial and temporal patterns of forest condition indicators. The annual assessment of the

Bundesamt für Umwelt (BAFU), Abteilung Wald, CH-3003 Bern, Switzerland

(a) Sabine Augustin

(Sabine.augustin@bafu.admin.de)

Received: Apr 25, 2008 - Accepted: Dec 09, 2008

Citation: Augustin S, 2009. Linking critical thresholds for acidity to forest condition by using element contents in tree rings: consequences for the development of an integrated ecosystem assessment. iForest 2: 51-53 [online: 2009-01-29] URL:

http://www.sisef.it/iforest/show.php? id $=473$ forest condition on Level I was complemented by the first soil condition survey (Vanmechelen et al. 1997) and the assessment of the forest foliar element survey on a subset of the plots (Stefan et al. 1997). While on the Level I plots no processes were studied, the monitoring on the 860 intensive monitoring plots of the Level II system helps to detect key processes of ecosystem functioning by means of analysing, e.g., element fluxes and tree growth (UNECE/EU 2004). Both systems together provide a good basis for the integrated evaluation of changes in the state of forest ecosystems. In the following, results were given on the link of element fluxes through forests to Mn contents in tree rings in order to detect incipient soil acidification. In 1988 the International Co-operative Programme on Modelling and Mapping of Critical Loads and Levels and Air Pollution Effects, Risks and Trends (ICP Modelling \& Mapping) was established with the aim to develop an effects-based approach for air pollution abatement policies. This was realised with the elaboration of methods to calculate critical loads for ecosystems. The critical load is "the highest deposition of acidifying compounds that will not cause chemical changes leading to long-term harmful effects on ecosystem structure and function" (Nilsson \& Grennfelt 1988). Critical loads were used in the negotiations of the Protocol on Further Reduction of Sulphur Emissions (Oslo - 1994), the Protocol on Abate Acidification, Eutrophication and Ground-level Ozone (Gothenburg - 1999) of the LRTAP Convention as well as the National Emission
Ceilings directive of the EU (NEC 2001).

\section{Results and discussion}

Within the framework of the German interdisciplinary case study "concept and feasibility study for the integrated evaluation of environmental monitoring data in forests", funded by the German Federal Ministry of Education and Research, data of the German Level I and II monitoring were evaluated (Augustin et al. 2005a). Additionally, data on tree growth and tree ring chemistry were assessed (Augustin et al. 2005b).

For acid deposition the most commonly used critical limit is about $\mathrm{pH} 4.2$, which is the thermodynamic threshold were aluminium oxides in soil dissolve. Potential toxic Al is released in the soil solution and "acid stress" for trees becomes possible. Between pH 5 to 4.2, manganese oxides are dissolved and taken up by plants. Thus, very high $\mathrm{Mn}$ concentration in soils and plants are an indicator of change in soil quality in the rooting zone (Guyette \& Cutter 1994) and the reaching of the critical limit. Changes in the availability of elements and effects of pollution can thus be detected in tree rings and assigned to a distinct time in the past (Guyette \& Cutter 1994, Ferretti et al. 2002, Poszwa et al. 2003).

The soil chemistry data from a Level I plot in the Thuringian forest were linked to tree chemical data to identify the time span of the attainment of the critical limits (German case study, for details see Augustin et al. 2005b). The tree rings of 60-year-old Norway spruce (Picea abies) show a distinct decline in the $\mathrm{Mn}$ concentration, beginning in the late 1960s and ending in the late 1970s. The dissolution and depletion of Mn oxides in soils precede the onset of an acid-stress situation for trees, which is characterized by a low availability of $\mathrm{Mg}$, low $\mathrm{pH}$ and increasing concentrations of Al. First studies on the observed "novel forest damage" for this region in 1984 show very low $\mathrm{Mg}$ contents in spruce needles and soils, leading to the deficiency symptoms. Often elevated Mn concentrations in plant organs distinguish damaged from undamaged tree collectives, and indicate the beginning of "novel forest damage" (Becher 1986, Gärtner et al. 1990). The depletion of the base cations in soil for this time was modelled (Augustin et al. 2005b). The result correspond to the measured data from this plot in the early 1990s (Level I soil condition survey).

The results show that in principle it is possible to link information of the environmental monitoring in forests with indicators from tree ring analysis to reconstruct soil chemical history on the medium time scale. It could be demonstrated, that the thermodynamic and empirical derived value of the critical limit 


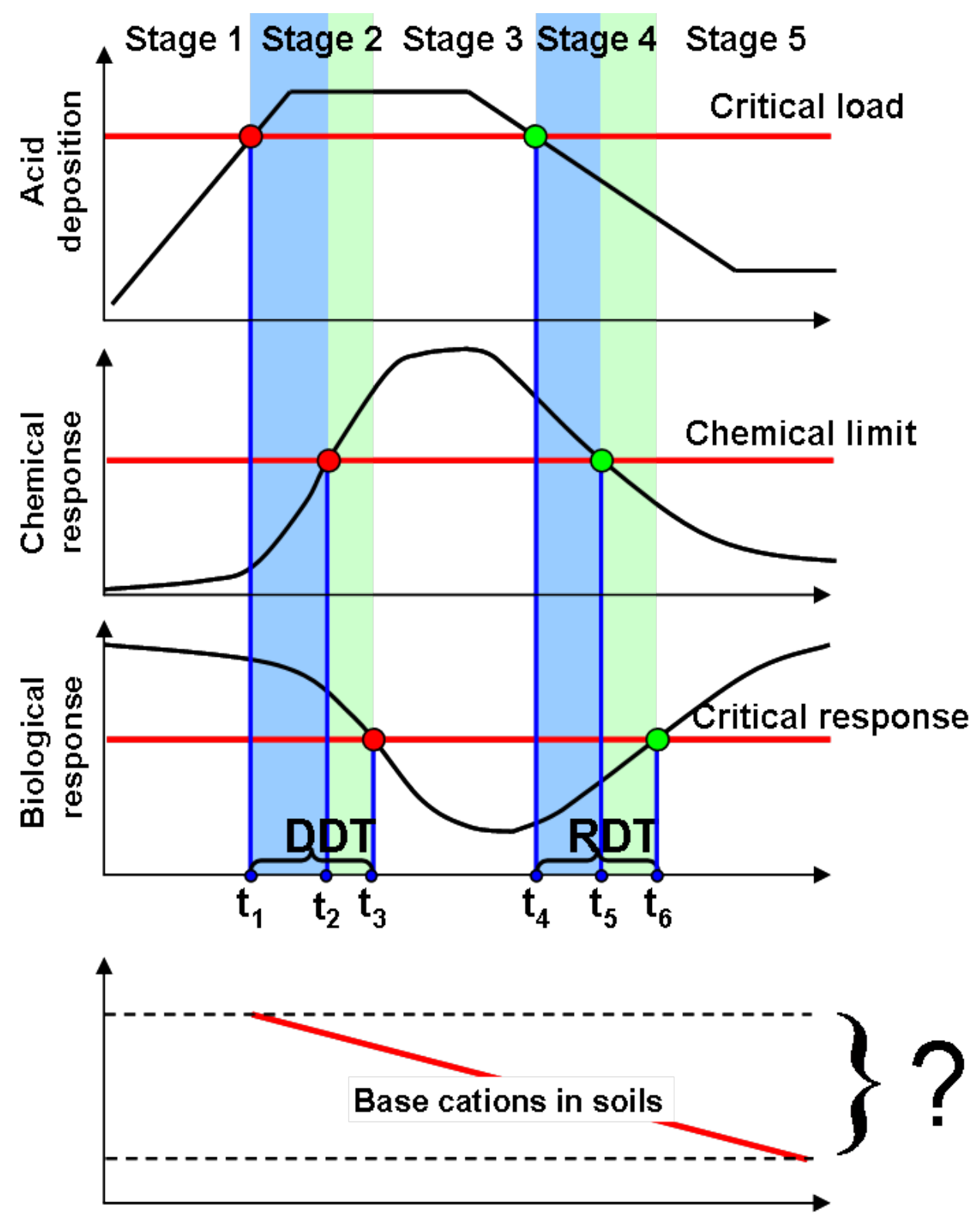

Fig. 1 - "Typical” temporal (past and future) development of the deposition (top), a soil chemical variable and the corresponding biological response. The delay between the (non-)exceedance of the critical load, the (non-)violation of the critical chemical criterion and the crossing of the critical biological response is indicated in grey shades, highlighting the Damage Delay Time (DDT) and the Recovery Delay Time (RDT) of the system. A fourth sub-figure is added indicating the possible trend of depletion of base cations associated with the exceedance of critical loads (acidity). (adapted from Posch \& Hettelingh 2001).

for acids is linked to the onset of damages. The effect based approach of the critical loads calculation is corroborated by the evaluation of ICP Forests data.

\section{Conclusions}

A critical load is an ecosystem property and the exceedance of a critical load indicates a long-term potential risk for an ecosystem. Damage symptoms do not necessarily show immediately. For instance, soils may buffer acid inputs for a certain time span. This is called "damage delay time" (Fig. 1). In contrast, the exceedance of a critical limit (e.g., $\mathrm{Bc} / \mathrm{Al}$ ratio in soil solution for acidity) indicates an "acid stress situation", finally leading to a "destabilizing" of the system with decline symptoms developing. If critical loads are exceeded, additional acids can not be neutralized and base cations will be mobilized and leave the ecosystem with the seepage water at an unsustainable rate. A net loss of bases is the consequence. This is often observed in regions with high deposition loads and can be calculated with dynamic models.

If $\mathrm{CL}$ for acidity are no longer exceeded we will come to a situation, were the ecosystems state is considerably changed because base capital is lost in times that exceeded critical loads (see also Grennfelt et al. 2001). Many different endpoints for chemical and biological responses are possible, leading to many different remaining risks for the vegetation. The often observed higher sensitivity of tree growth responses to environmental stress, starting in the 1970s, indicate a higher vulnerability to environmental stress (Beck \& Müller 2007, see also Dittmar \& Zech 1994) and must be seen in this context.

Today forests grow well (Spiecker et al. 1996), which is probably a consequence of nitrogen input but also enhanced $\mathrm{CO}_{2}$ concentration in the atmosphere and climate change. At the same time ecosystems are often eutrophied and their water filtering capacity is failing. Ecosystems recover from acidification, but in most cases they will not reach the "baseline" of an undisturbed, preindustrial status - which we in fact don't know. Additionally, the climate is changing, which will lead to a new "normal" state, if all depositions are below critical loads.

For the future risk assessment it is essential to define a "good ecological state" as a baseline for the whole forest ecosystem. The "good ecological state" can be defined as a sustainable situation without any risk for the integrity of forest ecosystems.

An appropriate evaluation system, applicable for different reporting obligations and environmental policy makers (LRTAP Convention, EU: Natura 2000, CBD: biod- 
iversity), should be developed in order to come to a sound scientific assessment of the actual state of ecosystems. The existing long-term and large scale forest monitoring of the ICP Forests provide the basis for this The system is flexible and upgradeable to include also new issues and to answer new questions.

\section{Acknowledgements}

The results are based on a study conducted within the framework of the combined project "Concept and Feasibility study for the Integrated evaluation of Environmental Monitoring data in Forests" (No. 0339985), funded by the German Ministry for Research and Education. We would like to thank for this financial support. Specially thanks to Dr. R. Loskill, Ms. H. Neumann, and Ms. P. Mahlitz.

\section{References}

Augustin S, Evers J, Dietrich H-D, Eichhorn J, Haussmann $\mathrm{T}$, Icke R, Isenberg A, Lux W, Musio M, Pretzsch H, Riek W, Rö;tzer T, Schultze B, Schulze A, Schröder J, Seidling W, Wellbrock N, von Wilpert K, Wolff B (2005a). Concept and feasibility study for the integrated evaluation of environmental monitoring data in forests. European Journal of Forest Resesrch 124: 251-260. - doi: 10.1007/s10342-005-0096-0 Augustin S, Stephanowitz H, Wolff, B, Schröder, J, Hoffmann E (2005b). Manganese in tree rings of Norway spruce as an indicator for soil chemical changes in the past. European Journal of Forest Research 124: 313-318. - doi: 10.1007/s10342-005-0084-4

Becher G (1986). Ergebnisse und methodisch-the- oretische Überlegungen zur immissionsökologischen Waldzustandserfassung (IWE) - dargestellt am Beispiel Hamburgs. Forstarchiv 57: 167-174.

Beck W, Müller J (2007). Impact of heat and drought on tree and stand vitality - dendroecological methods and first results from Level IIplots in southern Germany. Proceedings of the Symposium: "Forests in a changing environment - Results of 20 years ICP Forests Monitoring" (Göttingen NL, 25-28 October 2006). Schriften aus der Forstlichen Fakultät der Universität Göttingen und der Nordwestdeutschen Forstlichen Versuchsanstalt, Bd. 142: 120-127.

Dittmar C, Zech W (1994). Dendroökologische und ernährungskundliche Untersuchungen an gesunden und kranken Buchen (Fagus sylvatica L.) der Nordböhmischen Mittelgebirge. Dendrochronologia 12: 45-58.

Ferretti M, Innes JL, Jalkanen R, Saurer M, SchÃaffer J, Spiecker H, von Wilpert K (2002). Air pollution and environmental chemistry what role for tree-ring studies? Dendrochronologia 20: 159-174. - doi: 10.1078/1125-786500014

Gärtner EJ, Urfer W, Eichhorn J, Grabowski H, Huss H (1990). Mangan - ein Bioindikator für den derzeitigen Schadzustand mittelalter Fichten in Hessen. Forstarchiv 61: 229-233.

Guyette RP, Cutter BE (1994). Barium and manganese trends in tree-rings as monitors of sulfur deposition. Water Air and Soil Pollution 73: 213223. - doi: 10.1007/BF00477987

Grennfelt P, Moldan F, Alveteg M, Warfvinge P, Sverdrup H (2001). Critical loads - is there a need for a new concept? Water Air and Soil Pollution Focus 1: 21-27. - doi: 10.1023/A: 1011555132756

Nilsson J, Grennfelt P (1988). Critical loads for sulphur and nitrogen. Report from a workshop held at Skokloster, Sweden, 19-24 March 1988. NORD Miljørapport 1988: 15, Nordic council of Ministers, Copenhagen, Denmark, pp. 225-268. NEC (2001). Directive 2001/81/EC of the European parliament and of the council of 23 October 2001 on national emission ceilings for certain atmospheric pollutants.

Posch M, Hettelingh J-P (2001). From critical loads to dynamic modelling. In: "Modelling and mapping of critical thresholds in Europe". CCE Status Report 2001.

Poszwa A, Wickman T, Dambrine E, Ferry B, Dupouey J-L, Helle G, Schleser G, Breda N (2003). A retrospective isotopic study of Spruce decline in the Vosges mountains (France). Water Air and Soil Pollution Focus 3: 201-222. - doi: 10.1023/A:1022176025379

Spiecker H, Mielikäinen K, Köhl M, Skovsgaard J (1996). Growth trends in European forests. Springer-Verlag, Berlin, Heidelberg, pp. 372.

Stefan K, Fürst A, Hacker R, Bartels U (1997). Forest foliar condition in Europe. Results of the large-scale foliar chemistry surveys (survey 1995 and data from previous years). Brussels, Geneva, Vienna.

UNECE (2004). Manual on methodologies and criteria for modelling and mapping critical loads and levels and air pollution effects, risks and trends. [online] URL:http://www.icpmapping.org UNECE/EU (2004). Manual on methods and criteria for harmonized sampling, assessment, monitoring and analysis of the effects of air pollution on forests. BFH, Hamburg, Geneva.

Vanmechelen L, Groenemans R, Van Ranst E (1997). Forest soil condition in Europe. Results of the large-scale soil survey. Brussels, Geneva. 